\title{
THE INFLUENCE OF KNOWLEDGE ABOUT BREASTFEEDING MANAGEMENT IN REDUCING THE LEVEL OF ANXIETY IN WOMEN WITH POST CAESAREAN DELIVERY
}

\author{
Dewi Marfuah ${ }^{1}$, Annisa Nurfitriani Bachri \\ ${ }^{1}$ STIKEP PPNI JAWA BARAT \\ Correspondence: dewi.marfuah@yahoo.com
}

\begin{abstract}
Lactation management is management needed to support the success of breastfeeding. Based on the data obtained from Riskesdas in 2012, the incidence of early initiation of breastfeeding process in Indonesia was only $29.3 \%$, one of the influencing factor was the condition of post-cesarean women. Breastfeeding process for women with cesarean would be very hard and cause psychological problems, such as anxiety. This study aimed to determine the relations between knowledge of lactation management and anxiety in the breastfeeding process in women post cesarean delivery. This study was a correlation study with cross-sectional approach. The number of samples was calculated using Slovin formula, 59 women involved in this study that chosen using purposive sampling technique. The data were collected using the Hamilton Rating Scale for Anxiety (HARS) questionnaires and lactation management knowledge questionnaires. The relations analysis was performed using Spearman Rank Correlation. The result showed that $54.2 \%$ of mothers have moderate knowledge and $39.0 \%$ of them experience mild anxiety. Therefore, there was a significant relationship between the breastfeeding process and anxiety $\rho 0.001<0.05$. It can be concluded that there is a relation between knowledge of lactation management and anxiety in the breastfeeding process. Conclusion, It is suggested that nurses should provide nursing care on postnatal period, especially on how to give the appropriate breastfeeding so that anxiety in the breastfeeding process in the post of cesarean can be prevented.
\end{abstract}

Keywords: anxiety, breastfeeding, knowledge, lactation management, sectio caesarea

\section{INTRODUCTION}

Cesarean section surgery is giving birth through surgery by opening the abdominal wall and uterine wall due to certain indications (Prawirohardjo, 2009). According to Indonesia's Demographic and Health Survey (2012) stated that the rate of complications in cesarean section delivery was high, which is around 4-6 times higher than normal labor. One complication that occurs after cesarean delivery is a lactation issue (IDHS, 2012). Women who gave birth by cesarean had a tendency to experience breastmilk production disorders caused by the difficulty of early initiation of breastfeeding which resulted in reducing let down stimulation reflex from the baby's suction during the first breastfeeding, and less optimal prolactin levels (Zamzara, et.al, 2015). The reduced stimulation of let-down reflex causes a decrease in oxytocin hormone in post-cesarean women which has an impact on the process of breastfeeding, and women tend to delay breastfeeding (Kause, et. Al, 2016). 
Women who gave birth by cesarean delivery were 3 times more at risk for stopping breastfeeding in the first month of postpartum, because the absence of early initiation of breastfeeding and delay in giving breast milk compared to women who gave birth normally (Chertox \& Vardi, 2012). The delay in giving breastmilk postcesarean delivery occurs because breast milk comes out more than 2-7 days after delivery. The inability of breastfeeding would affect the low coverage of exclusive breastfeeding (Cunningham, 2010).

World Health Organization (WHO) in 2012 explained that there were $35.6 \%$ of women failing to breastfeed their babies and $20 \%$ in developing countries including Indonesia. In Indonesia, the overall behavior of exclusive breastfeeding tends to decrease. Meanwhile, based on the 2013 Basic Health Research Data (Riskesdas), the coverage of breastfeeding in Indonesia was only $42 \%$. In West Java, the number of babies who obtain exclusive breastfeeding continues to decline by only around $24 \%$. This figure was under the WHO target which is $50 \%$ of the baby should obtain the exclusive breastfeeding, and the national target is $80 \%$ (Indonesian Ministry of Health, 2013).

6 months of exclusive breastfeeding would prevent deaths of infants under 5 years of age by $13 \%$ (Riksani, 2012). This was supported by government policy with the issuance of PP No. 33 of 2012 concerning exclusive breastfeeding. This policy protects the baby's right to get breastmilk and women's rights to breastfeed their babies (Ministry of Health, 2012). Rofiuddin's (2012) study identified factors that cause low exclusive breastfeeding in Indonesia including psychological factors (51.3\%) and physical factors $(46,2 \%)$. The psychological factors include anxiety, lack of confidence, feeling depressed, and various emotional tensions. The physical factors are women's diseases, contraceptive pills, and alcoholic drinkers. These conditions might impact exclusive breastfeeding achievement. Another factor is women's knowledge of exclusive breastfeeding, and how to breastfeed appropriately. Women's knowledge is influenced by sources of information, health 
professionals, and parity or number of children. Knowledge has the largest percentage of causes of breastfeeding problems.

Lactation management in the post-cesarean delivery focus on the position of the baby in the process of breastfeeding. The position of breastfeeding greatly determines success in the breastfeeding process. The recommended breastfeeding position for the post-cesarean delivery is to flank the baby in the armpit, lying down is the best breastfeeding position for women's comfort on the first day of delivery (Lowdermilk, et.al., 2013). This is because women with cesarean deliveries require a longer recovery time of around 2 to 3 months compared with normal post-partum. Sometimes women feel weak, it impacted women limited mobilization. Women with general anesthesia are relatively unconscious and not able to take care of their babies in the first hour after the baby is born so the process of initiating early breastfeeding is not fulfilled (Desmawati, 2013).

Anxiety is one of the psychological effects that appear in postpartum women, for example, a little volume of breastmilk. The role of nurses is very necessary for the provision of knowledge and becoming a counselor for post-cesarean women especially women with problems in lactation (Istiyati, 2014). Based on the preliminary study at Dustira Hospital, Cimahi City found that the number of women post-cesarean for the past 1 year was 1278 people. This study aimed to determine the relations between knowledge of lactation management and anxiety in the breastfeeding process in women post cesarean delivery.

\section{METHODS}

This type of research was descriptive analytic research. The independent variable in this study was knowledge of lactation management, and the dependent variable was anxiety in the breastfeeding process. The population in this study were 141 post-cesarean women in the Postpartum Room in Dustira Hospital Cimahi City, and the number of samples was 59 
people. Samples were selected by purposive sampling technique. The instrument in this study was a questionnaire to determine women's knowledge about lactation management and the level of anxiety in the breastfeeding process. The lactation management knowledge questionnaire was developed based on the theories of Kristiyanasari (2009), Walyani, and Purwoastuti (2015), Regina (2011), and Lowdermilk, Perry, \& Cashion (2013) with validity test values> 0.361 and Reliability test values 0.875 . The question consists of 25 questions, with a Guttmann scale. The instrument to measure the level of anxiety used the Hamilton Anxiety Rating Scale (HARS) questionnaire. The bivariate analysis in this study used the Spearman Rank Correlation (Arikunto, 2010).

\section{RESULTS}

\section{A. Characteristics of Respondents}

The results showed that $52.5 \%$ of respondents aged $26-35,67.8 \%$ of respondents attended a high school education level, $72.9 \%$ of respondents were housewives, and $61 \%$ were multiparous postpartum.

Table 1. Characteristics of respondent

\begin{tabular}{|c|c|c|c|}
\hline No. & Characteristic & Frequency & $\%$ \\
\hline \multirow[t]{4}{*}{1.} & Age (years) & & \\
\hline & $16-25$ & 20 & $33,9 \%$ \\
\hline & $26-35$ & 31 & $52,5 \%$ \\
\hline & $36-45$ & 8 & $13,6 \%$ \\
\hline \multirow[t]{5}{*}{2.} & Education & & \\
\hline & Elementary & 4 & $6,8 \%$ \\
\hline & Junior High School & 5 & $8,5 \%$ \\
\hline & Senior High School & 40 & $67,8 \%$ \\
\hline & University & 10 & $16,9 \%$ \\
\hline \multirow[t]{4}{*}{3.} & Occupation & & \\
\hline & Government offices & 3 & $5.1 \%$ \\
\hline & Private & 13 & $22 \%$ \\
\hline & Housewives & 43 & $72.9 \%$ \\
\hline \multirow[t]{5}{*}{4} & Parity & & \\
\hline & Primi parous & 22 & $37.3 \%$ \\
\hline & Multiparous & 36 & $61 \%$ \\
\hline & Grand multiparous & 1 & $1.7 \%$ \\
\hline & Total & & $100 \%$ \\
\hline
\end{tabular}




\section{B. Knowledge of Lactation Management}

The results showed that the majority of respondents had a moderate level of lactation management knowledge $(54.2 \%)$ of 32 people. The frequency of women with moderate knowledge was higher than women with good knowledge. The different number of women with low knowledge and good knowledge was 17, and the difference in the number of women with moderate knowledge with low knowledge was 22 people.

Table 2. Knowledge of lactation management in post-cesarean women

\begin{tabular}{cccc}
\hline No. & Knowledge & Frequency & \% \\
\hline 1. & Good & 17 & $28,8 \%$ \\
2. & Moderate & 32 & $54,2 \%$ \\
3. & Low & 10 & $16,9 \%$ \\
\hline \multicolumn{5}{r}{ Total } & $\mathbf{1 0 0 \%}$ \\
\hline
\end{tabular}

\section{Anxiety in the Breastfeeding Process}

This study found that the majority of respondents had experienced mild anxiety (39\%), 14 women (23.7\%) experienced severe anxiety. The frequency of women who experience mild anxiety was higher than those who experience moderate and severe anxiety.

Table 3. Anxiety in the Breastfeeding Process in Women Post Caesarean

\begin{tabular}{cccc}
\hline No. & Anxiety & Frequency & \% \\
\hline 1. & mild & 23 & $39,0 \%$ \\
2. & moderate & 22 & $37,3 \%$ \\
3. & severe & 14 & $23,7 \%$ \\
\hline \multicolumn{5}{r}{ Total } & & $\mathbf{1 0 0 \%}$ \\
\hline
\end{tabular}

\section{DISCUSSION}

Knowledge of lactation management is an understanding of management to support the success of the breastfeeding process by teaching women how to breastfeed appropriately, and the steps in breastfeeding. In fact, not all women understand lactation management. A person's knowledge is different with others, so knowledge would directly or indirectly affect humans' life. 
Anxiety is influenced by threat factors including self-integrity. These threats include physiological inability or disruption of basic needs such as assessing anxiety as a subjective experience as a basis for perceptions of the situation that occurs (Stuart \& Sundeen, 2006). Anxiety also has characteristics such as feelings of fear, and unpleasant vigilance (Fauziah \& Widury, 2007). Symptoms that arise including dizziness, tired body, sweating a lot, trembling, feathers on the neck, and sleep disturbances. These symptoms often appear in post-cesarean women when breastfeeding their babies (Rochman, 2010). Women with cesarean delivery have a tendency to experience milk production issues. The disorder occurs because of the difficulty of early initiating breastfeeding that may be effected in reducing let down stimulation from the baby's during the first breastfeeding, and the prolactin level is less optimal. Reducing stimulation of let-down reflex causes a decrease in the oxytocin hormone and it influenced by the psyche of women. Therefore, breastfeeding women who experience anxiety or stress would be impacted flow, as a result, breast milk would not be able to come out immediately after giving birth (Kristiyanasari, 2009).

There is a relationship $(\rho=0.001)$ between lactation management knowledge and anxiety in the breastfeeding process. This study assessed the variables of anxiety in the breastfeeding process with 9 indicators in the lactation management knowledge questionnaire. The correlation between the relationship of knowledge of lactation management and anxiety in the breastfeeding process is quite strong, and the direction of this relationship is positive. There were 3 indicators related to anxiety in the breastfeeding process including indicators of breastmilk composition with $\rho 0.04<0.05$, indicators of efforts in lactation with P $0.02<0.05$, and an indicator of how to breastfeed with $\mathrm{P}$ value $0.00<0.05$. A positive correlation means that the better the knowledge about lactation management, the lighter the level of anxiety in the breastfeeding process. This shows that knowledge of lactation management affects anxiety in the breastfeeding process in women post-cesarean. 
Wong (2009) suggested that the emergence of someone's anxiety was influenced by several factors, including the level of knowledge, age, gender, education, economic status, length of stay and nurse's behavior. One of the factors that influence anxiety is knowledge. The theory was supported by the result of Basic Health Research Data (2013) which explained that $67.5 \%$ of women who failed to give exclusive breastfeeding to their babies were due to a lack of knowledge of women about lactation management. There were some problems experienced in breastfeeding, including emotional periods; changes in mood, anxiety, dizziness, and feelings of sadness (Bahiyyatun, 2009). According to Notoatmodjo (2012), the level of women's anxiety during the breastfeeding process is influenced by knowledge.

\section{CONCLUSION}

There is a significant relationship between knowledge about lactation management and anxiety in the breastfeeding process. The better the knowledge of women about lactation management, the lower the level of anxiety in the breastfeeding process in post-cesarean women. Nurses are expected to increase their role in education related to lactation management to reduce anxiety in the breastfeeding process in post-cesarean women so the baby obtains exclusive breastfeeding for 6 months.

\section{REFERENCES}

Bahiyyatun. (2009). Buku Ajar Asuhan Kebidanan Nifas Normal. Jakarta: EGC.

Chertok, I. R., \& Vardi, I. S. (2012). Infant hospitalization and Breastfeeding Post Caesarea Section. British Jurnal of Nursing. 17, (12), 786-791.

Cunningham. F. G. (2010). Obstetri Williams. Jakarta: EGC. 
Dewi Marfuah : The Influence of Knowledge about Breastfeeding Management

Departemen Kesehatan Republik Indonesia. (2013). Manajemen Laktasi: Buku Panduan Bagi Bidan dan Petugas Kesehatan di Puskesmas. Jakarta: Direktorat Gizi Masyarakat Departemen Kesehatan Republik Indonesia.

Desmawati. (2013). "Penentu Kecepatan Pengeluaran Air Susu Ibu Setelah Sectio Caesarea". Artikel Penelitian Fakultas Ilmu Kesehatan UPN Vateran. 4, (8), 360-363.

Istiyati, S., Haryanto, S., \& Subandono, J. (2014). Pelaksanaan Discharge Planning Pada Pasien Post Sectio Caesarea. Jurnal Kebidanan Keperawatan. 10, (2), 103-114.

Kause, M., Trisetiyaningsih, Y., \& Sukmawati, A. (2016). Onset Pengeluaran Kolostrum Persalinan Normal Lebih Cepat daripada Persalinan Sectio Caesarea. Jurnal Media Ilmu Kesehatan. 5, (3), 193-199.

Kristiyanasari, W. (2009). ASI Menyusui dan SADARI. Yogyakarta: Nuha Medika.

Lowdermilk, D., Perry, J., \& Cashion, K. (2013). Keperawatan Maternitas. Jakarta: PT Salemba Emban Patria.

Notoatmodjo. (2012). Metode Penelitian Kesehatan. Jakarta: PT Rineka Cipta.

Prawirohardjo, S. (2010). Ilmu Kebidanan $\left(4^{\text {th }} e d\right)$. Jakarta: PT Bina Pustaka Sarwono Prawirohardjo.

Riksani, R. (2012). Keajaiban ASI (Air Susu Ibu). Jakarta: Dunia Sehat.

Riset Kesehatan Dasar (RISKESDAS). (2013). Jakarta: Badan Penelitian dan Pengembangan Kesehatan Departemen Republik Indonesia.

Saleha. (2009). Asuhan Kebidanan Pasa Masa Nifas. Jakarta: Salemba Medika.

Stuart,G.W., \& Sundeen. (2006). Buku Saku Keperawatan Jiwa. Jakarta: WGC.

Zamzara, R., Ernawati, D., \& Susanti, A. (2015). Pengaruh Pijat Oksitosin Terhadap Waktu Pengeluaran Kolostrum Ibu Post Partum Sectio Caesarea. Jurnal Ilmiah Kesehatan. 8, (2), 229-241. 